\title{
ANALISIS FAKTOR-FAKTOR YANG MEMPENGARUHI ADOPSI $E$ COMMERCE DAN PENGARUHNYA TERHADAP KINERJA UMKM (STUDI KASUS UMKM DI WILAYAH KOTA SEMARANG)
}

\author{
Ayu Noviani Hanum \\ Universitas Muhammadiyah Semarang \\ ayu.hanum@unimus.ac.id \\ Andwiani Sinarasri \\ Universitas Muhammadiyah Semarang \\ andwi_fe@yahoo.com
}

\begin{abstract}
E-Commerce sering disebut sebagai salah satu pendorong pertumbuhan ekonomi di Indonesia.) Besarnya potensi e-commerce tidak lepas dari perkembangan pengguna internet di Indonesia. Pada tahun 2015, pengguna internet di Indonesia mencapai 93,4 juta jiwa, meningkat cukup pesat jika dibandingkan dengan 88,1 juta jiwa pada 2014. Potensi e-commerce terlihat dari angka $77 \%$ dari penggunaan internet digunakan untuk mencari informasi produk dan berbelanja online, pelanggan online shop yang mencapai 8,7 juta orang, dan nilai transaksi yang diprediksi mencapai US\$ 4,89 Miliar pada tahun 2016. Usaha Kecil Mikro dan Menengah (UMKM) di Indonesia memiliki peranan penting dalam perekonomian nasional. UMKM dituntut untuk melakukan perubahan dan inovasi untuk meningkatkan daya saing, salah satunya adalah dengan memanfaatkan e commerce.

Tujuan penelitian ini adalah untuk mengetahui dan menganalisis pengaruh faktor teknologi, organisasional, lingkungan dan individual terhadap adopsi $e$ commerce serta menganalisis pengaruh adopsi $e$ commerce terhadap kinerja UMKM. Metode pengumpulan data dilakukan melalui penyebaran kuesioner dan wawancara pada 100 UMKM di Kota Semarang. Metode analisis dalam penelitian ini menggunakan perhitungan regresi berganda dengan menggunakan SPSS 20.0 untuk melihat pengaruh tidak langsung antara satu variable dengan variable lainnya.

Hasil uji t dalam penelitian ini menunjukkan bahwa faktor teknologi dan faktor individual secara parsial berpengaruh positif dan signifikan terhadap adopsi e commerce. Sebaliknya faktor organisasional secara parsial berpengaruh negatif dan tidak signifikan terhadap adopsi e commerce dan faktor lingkungan secara parsial berpengaruh positif dan tidak signifikan terhadap adopsi e commerce pada UMKM di Kota Semarang. Hasil uji F menunjukkan bahwa secara simultan faktor kesiapan teknologi, organisasional, lingkungan dan individual berpengaruh secara bersama-sama terhadap adopsi e commerce pada UMKM di Kota Semarang.
\end{abstract}

Kata Kunci : e commerce, teknologi, organisasional, lingkungan dan individual 


\section{PENDAHULUAN}

\section{Latar Belakang}

E-Commerce sering disebut sebagai salah satu pendorong pertumbuhan ekonomi di Indonesia. Hal ini bukan tanpa alasan sebab dengan jumlah penduduk dan penetrasi internet yang bertumbuh pesat, Indonesia merupakan salah satu pasar potensial e-Commerce. Menurut kominfo.go.id (12/11/15) Besarnya potensi $e$ commerce tidak lepas dari perkembangan pengguna internet di Indonesia. Pada tahun 2015, pengguna internet di Indonesia mencapai 93,4 juta jiwa, meningkat cukup pesat jika dibandingkan dengan 88,1 juta jiwa pada 2014. Potensi $e$ commerce terlihat dari angka $77 \%$ dari penggunaan internet digunakan untuk mencari informasi produk dan berbelanja online, pelanggan online shop yang mencapai 8,7 juta orang, dan nilai transaksi yang diprediksi mencapai US\$ 4,89 Miliar pada tahun 2016. Ini meningkat dibanding tahun 2015. Data dari lembaga riset ICD memprediksi bahwa pasar $e$ commerce di Indonesia akan tumbuh $42 \%$ dari tahun 2012-2015. Angka ini lebih tinggi jika dibandingkan negara lain seperti Malaysia (14\%), Thailand (22\%), dan Filipina (28\%)

Potensi UMKM dalam menggerakkan perekonomian harus diperhatikan, dan UMKM dituntut untuk melakukan perubahan dan inovasi untuk meningkatkan daya saing. Chandler dalam Ningtyas PK (2015) mengemukakan bahwa sebuah perusahaan merupakan organisasi yang sangat dinamis sehingga memerlukan penyesuaian-penyesuaian untuk dapat bersaing, salah satunya adalah dengan memanfaatkan e commerce.

Sesuai data Dirjen Industri KecilMenengah Kementerian Perindustrian pada tahun 2014 dari jumlah UKM itu, hanya 30-40 persen yang sudah memanfaatkan kecanggihan untuk mengembangkan bisnisnya. Berdasarkan hal tersebut maka peneliti bermaksud melakukan penelitian terkait Analisis Faktor-Faktor yang mempengaruhi adopsi $e$ commerce dan pengaruhnya terhadap kinerja UMKM. Penelitian ini mengadopsi penelitian yang di lakukan oleh Rahayu dan Day (2015) ditambah dengan beberapa faktor yang dimasukkan dalam instrumen survey yang diambil dari penelitian Wymer dan Regan (2005) serta ditambah dengan beberapa pertanyaan terbuka kepada responden.

\section{Rumusan Masalah}

Berdasarkan latar belakang penelitian tersebut di atas, maka rumusan masalah penelitian ini adalah sebagai berikut :
1. Apakah faktor teknologi berpengaruh positif dan signifikan terhadap adopsi $e$ commerce pada UMKM di Kota Semarang?

2. Apakah faktor organisasional berpengaruh positif dan signifikan terhadap adopsi $e$ commerce pada UMKM di Kota Semarang?

3. Apakah faktor lingkungan berpengaruh positif dan signifikan terhadap adopsi $e$ commerce pada UMKM di Kota Semarang?

4. Apakah faktor individual berpengaruh positif dan signifikan terhadap adopsi $e$ commerce pada UMKM di Kota Semarang?

5. Apakah faktor teknologi, organisasional, lingkungan dan individual secara simultan berpengaruh positif dan signifikan terhadap adopsi e commerce?

6. Apakah adopsi e commerce berpengaruh positif dan signifikan terhadap kinerja UMKM di Kota Semarang.

\section{TINJAUAN PUSTAKA}

\section{Landasan Teori}

\section{Pengertian $E$-commerce}

Electronic Commerce (e-commerce) merupakan konsep baru yang biasa digambarkan sebagai proses jual beli barang atau jasa pada World Wide Web Internet (Shim, Qureshi, Siegel, 2000) atau proses jual beli atau pertukaran produk, jasa dan informasi melalui jaringan informasi termasuk internet (Turban, Lee, King, Chung, 2000). Penggolongan e-commerce yang lazim dilakukan orang ialah berdasarkan sifat transaksinya. Menurut Suyanto (2003:45) tipetipe berikut segera bisa dibedakan :

1. Business to business (B2B), adalah model $e$ commerce dimana pelaku bisnisnya adalah perusahaan, sehingga proses transaksi dan interaksinya adalah antara satu perusahaan dengan perusahaan lainnya.

2. Business to Consumer (B2C), adalah model $e$ commerce dimana pelaku bisnisnya melibatkan langsung antara pihak penjual (penyedia jasa e commerce) dengan individual atau pembeli.

3. Consumer to Consumer $(C 2 C)$, adalah model e-commerce dimana perorangan atau individu sebagai penjual berinteraksi dan bertransaksi langsung dengan individu lain sebagai pembeli. Konsep e-commerce jenis ini banyak digunakan dalam situs lelang secara online

4. Consumer to Business (C2B), adalah model ecommerce dimana pelaku bisnis perorangan atau individual melakukan transaksi atau interaksi dengan suatu atau beberapa 
perusahaan. Jenis e-commerce seperti ini sangat jarang dilakukan di Indonesia.

\section{Teknologi}

Faktor teknologi terdiri dari beberapa indikator, seperti manfaat yang dirasakan, kesesuaian, dan biaya yang mempengaruhi adopsi teknologi e commerce. Manfaat yang dirasakan adalah tingkat penerimaan keuntungan yang akan diperoleh bagi perusahaan (Tiago \& Maria, 2010). Semakin baik pemahaman pihak manajerial terkait keuntungan relatif dari pengadopsian e commerce akan membuat perusahaan mengalokasikan beberapa sumberdaya, seperti sumberdaya manajerial, keuangan dan teknologi. Kesesuaian adalah sejauh mana $e$ commerce sesuai dengan insfrastuktur teknologi, budaya, nilai dan praktik kerja yang sudah ada sebelumnya pada perusahaan (Morteza, Daniel \& Jose, 2011). Sebuah inovasi akan mudah untuk di terima oleh sebuah organisasi jika sudah sesuai dengan nilai yang berlaku dalam organisasi, dapat memahami kebutuhan dan sesuai dengan budaya organisasi. Pada kasus ini, biaya menjadi salah satu faktor yang mempengaruhi UMKM di Indonesia dalam mengadosi e commerce. Biasanya semakin murah biaya teknologi yang digunakan, akan semakin cepat di adopsi dan di implementasikan dalam sebuah organisasi (Premkumar \& Robert,1999 dalam Rahayu \& Day, 2015).

\section{Organisasional}

Faktor organisasional merupakan karakteristik perusahaan yang dapat mempengaruhi adopsi teknologi e commerce. Beberapa indikator aspek organisasional adalah kesiapan teknologi, ukuran perusahaan. Kesiapan teknologi adalah salah satu faktor penentu yang mempengaruhi adopsi e commerce, yang merupakan sejauh mana infrastruktur teknologi sesuai dengan sistem dan kemapuan teknikal pada bisnis mampu mendukung adopsi e commerce (Zhu dkk, 2006). Kesiapan teknologi terdiri dari teknologi infrastruktur dan tenaga teknologi informasi (Zhu \& Kraemer, 2005) dan keduanya mutlak dibutuhkan jika perusahaan ingin mengadopsi $e$ business sebagai sebuah bagian integral dari rantai nilai. (Tiago \& Maria, 2010). Faktor lain yang berpengaruh adalah ukuran perusahaan (firm size), karena ukuran perusahaan berhubungan dengan kemampuan perusahaan untuk menyiapkan sumberdaya seperti keuangan dan sumber daya manusia. Semakin besar ukuran perusahaan maka semakin besar kemampuan untuk menyiapkan sumber daya yang dibutuhkan, dan lebih memungkinkan untuk mengadopsi teknologi e commerce.

\section{Lingkungan}

Aspek lingkungan adalah pengaruh eksternal, seperti tekanan dari konsumen/supplier, pesaing dan dukungan eksternal lainnya yang mempengaruhi adopsi e commerce. Semakin tinggi tekanan dari rekan bisnis maka akan memungkinkan perusahaan untuk mengadopsi $e$ commerce dengan tujuan untuk mempertahankan posisi kompetitif mereka (Duan,Deng \& Corbitt, 2012).

Semakin tinggi tekanan dari kompetitor dalam sebuah industri, perusahaan akan dipaksa untuk mengadopsi teknologi e commerce untuk memperoleh keuntungan yang kompetitif. Semakin tinggi tingkat persaingan dalam sebuah industri, makin besar pula manfaat yang diperoleh dari pengadopsian e commerce. (Zhu \& Kraemer, 2005). Selain itu pemerintah dan pihak penyedia teknologi informasi adalah sebagai salah satu faktor yang yang mempengaruhi adopsi $e$ commerce. Berdasarkan hasil penelitian dari Rahayu dan Day (2015) menemukan bahwa konteks lingkungan tidak memiliki pengaruh terhadap adopsi e commerce, sedangkan hasil penelitian dari Ningtyas dkk (2015) menyatakan bahwa dorongan eksternal/lingkungan diluar perusahaan berpengaruh positif terhadap adopsi $e$ commerce.

\section{Individual}

Selain ketiga aspek yang dijelaskan diatas, individual ini juga termasuk sebagai faktor penentu bagi adopsi e commerce pada UMKM di negara-negara berkembang (Rita \& Day, 2015). Ini disebabkan kebanyakan adopsi e commerce oleh UMKM secara ekstensif bergantung pada penerimaan pemilik usaha terhadap teknologi e commerce. Hal ini sangat beralasan karena UMKM secara struktural cenderung pengelolaannya terpusat, karena pemilik usaha/manajer memiliki peran penting dalam pembuatan keputusan (Nguyen \& Waring, 2013). Indikator yang digunakan dalam penelitian ini adalah inovasi dari pemilik usaha, pengalaman dan kemampuan penggunaan teknologi informasi dari pemilik. Inovasi dari pemilik adalah sejauh mana pemiliki usaha mengadposi inovasi lebih cepat dibandingkan lainnya dalam konteks sosial (Marcati,Guido, Peluso,2008), sedangkan jika pemilik usaha memiliki pengalaman dan kemampuan terkait teknologi informasi, mereka akan percaya diri dan lebih cepat dalam mengadopsi e commerce. Yang terpenting adalah jika pemilik usaha memahami dengan baik terkait fungsi dan manfaat dari adopsi e commerce, mereka akan lebih cepat untuk mengadopsinya (Rahayu dan Day, 2015).

\section{Kinerja Perusahaan Pengadopsian E-commerce Kinerja perusahaan merupakan suatu}


ukuran yang dipakai untuk mengukur keberhasilan perusahaan dalam mencapai tujuan yang telah ditetapkan dimana suatu perusahaan dikatakan mengalami keberhasilan dalam bidangbidang apabila praktek yang ada cocok dengan semua kebutuhan konstituensi (Kotter dan Heskett, 1992). Menurut Kraemer et al.(2002) kinerja perusahaan dapat diukur melalui 3 hal yaitu efisiensi, koordinasi dan perdagangan (posisi pasar dan penjualan) dimana ketiga hal tersebut diharapkan dapat diperoleh dari adopsi teknologi informasi baru oleh suatu perusahaan.

Peningkatan kinerja dapat berupa pengurangan biaya transaksi dan koordinasi aktifitas ekonomi yang lebih dekat antar rekan bisnis (Malone et al., 1987; Mukhopadhyay et al., 1995 dalam Kraemer et al., 2002). Secara khusus e-commerce diprediksi akan menurunkan biaya koordinasi dan transaksi karena otomasi online transaksi, begitu juga produktifitas dan peningkatan efisiensi (Amit dan Zott, 2001; Lucking-Reiley dan Spulbur, 2001; Wigand dan Benjamin, 1995 dalam Kraemer et al., 2002).

Berdasarkan latar belakang tersebut, perlu dilakukan penelitian mengenai faktorfaktor apa saja yang berpengaruh terhadap adopsi e-commerce pada UMKM di Kota Semarang. Penelitian ini bertujuan untuk mengetahui sejauhmana adopsi $e$ - commerce dapat berpengaruh pada kinerja UMKM di Kota Semarang.

\section{METODE PENELITIAN}

\section{Jenis Penelitian}

Jenis penelitian ini termasuk penelitian survei, dan dalam pengambilan kesimpulan dilakukan dengan melalui pengujian hipotesis

\section{Objek Penelitian}

Obyek penelitian ini adalah pelaku UMKM di wilayah Kota Semarang yang sudah memanfaatkan teknologi internet dalam menjalankan usahanya.

\section{Kerangka Pemikiran Teoritis}

Kerangka pemikiran teoritis yang dikembangkan dalam penelitian ini mengacu pada telaah pustaka yang telah dibahas pada sub bab sebelumnya. Berdasarkan uraian dan penjelasan tersebut, maka kerangka kerangka pemikiran teoritis yang diajukan dalam penelitian ini adalah seperti pada Gambar 2.1 di bawah ini :

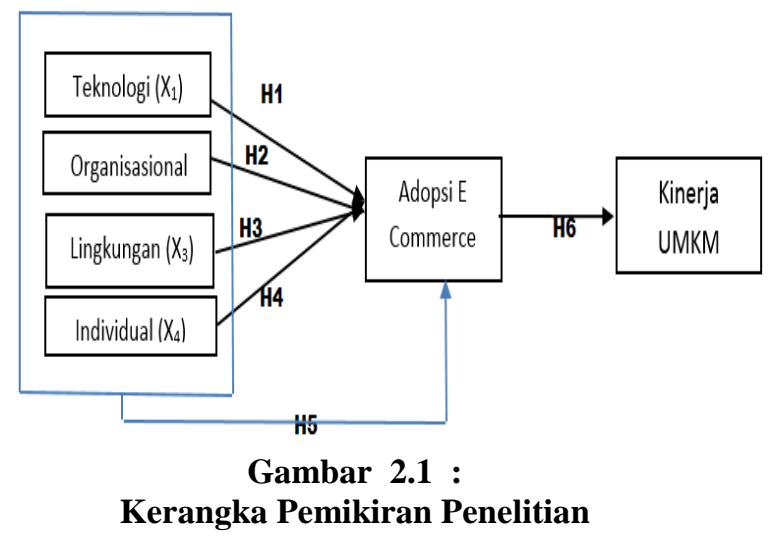

4. Hipotesis

Seperti yang telah dikemukakan sebelumnya, hipotesis yang diajukan dalam penelitian ini adalah sebagai berikut :

$\mathrm{H}_{1}$ : Faktor teknologi mempunyai pengaruh positif dan signifikan terhadap pengadopsian E-commerce pada UMKM

$\mathrm{H}_{2}$ :dFaktor organisasional mempunyai pengaruh positif dan signifikan terhadap pengadopsian E-commerce pada UMKM di Kota Semarang

$\mathrm{H}_{3}$ : Faktor lingkungan mempunyai pengaruh positif dan signifikan terhadap pengadopsian E-commerce pada UMKM di Kota Semarang

$\mathrm{H}_{4}$ : Faktor individual mempunyai pengaruh positif dan signifikan terhadap pengadopsian E-commerce pada UMKM di Kota Semarang

$\mathrm{H}_{5 \text { :dd }}$ Faktor teknologi, organisasional, lingkungan dan individual secara simultan berpengatuh positif dan signifikan terhadap adopsi $e$ commerce pada UMKM di Kota Semarang

$\mathrm{H}_{6}$ : Pengadopsian e-commerce mempunyai pengaruh positif dan signifikan terhadap kinerja perusahaan UMKM di Kota Semarang

\section{METODE PENELITIAN}

\section{Metode Pengumpulan Data}

Metode pengumpulan data dilakukan dengan

1. Kuesioner

Pencarian data dilakukan dengan membagi kuesioner kepada pelaku UMKM di Kota Semarang secara online maupun on line

2. Wawancara

Wawancara dilakukan untuk mendapatkan gambaran yang lebih detail mengenai obyek penelitian.

\section{Variabel Penelitian dan Definisi Operasional Variabel}

$>$ Variabel Penelitian 
Variabel yang terdapat dalam penelitian ini adalah variabel terikat (dependen) dan variabel bebas (Independen). Variabel bebas adalah variabel yang mempengaruhi variabel lain, sedangkan variabel terikat adalah variabel yang dipengaruhi oleh variabel lain. Variabel terikat pada penelitian ini adalah Adopsi e-commerce, dan Kinerja UMKM, dan variabel bebas pada penelitian ini yaitu faktor teknologi, organisasional, lingkungan dan individual. Variabel ini diukur dengan menggunakan skala likert interval 7 dengan instrumen yang dikembangkan dari kuesioner Rahayu dan Day, 2015 ditambah dengan beberapa indikator yang digunakan dalam penelitian Wymer dan Regan (2005) serta ditambah dengan beberapa pertanyaan terbuka kepada responden.

\section{$>$ Definisi Operasional Variabel}

1. Kinerja perusahaan merupakan suatu ukuran yang dipakai untuk mengukur keberhasilan perusahaan dalam mencapai sebuah tujuan yang telah ditetapkan dimana suatu perusahaan dikatakan mengalami keberhasilan dalam bidang-bidang apabila praktik yang ada cocok dengan semua kebutuhan konstitueni (Kotter dan Heskett, 1992). Menurut Kreamer et al (2002) kinerja perusahaan dapat diukur melalui 2 hal yaitu efisiensi, koordinasi dan perdagangan (posisi pasar dan penjualan) dimana ketiga persoalan tersebut diharapkan dapat diperoleh melalui adopsi teknologi baru oleh suatu perusahaan/ Peningkatan kinerja dapat berupa pengurangan biaya transaksi dan koordinasi aktifitas ekonomi yang lebih dekat antar rekan bisnis .

2. Adopsi e commerce adalah keputusan dari pemilik dan manajer puncak UMKM di Kota Semarang untuk menggunakan sepenuhnya ide baru berupa e commerce sebagai cara untuk melakukan transaksi jual beli.

3. Faktor teknologi terdiri dari beberapa indikator, seperti manfaat yang dirasakan, kesesuaian, dan biaya yang mempengaruhi adopsi teknologi e commerce. Manfaat yang dirasakan adalah tingkat penerimaan keuntungan yang akan diperoleh bagi perusahaan (Tiago \& Maria, 2010). Semakin baik pemahaman pihak manajerial terkait keuntungan relatif dari pengadopsian e commerce akan membuat perusahaan mengalokasikan beberapa sumberdaya, seperti sumberdaya manajerial, keuangan dan teknologi. Biaya menjadi salah satu faktor yang mempengaruhi UMKM di Indonesia dalam mengadosi e commerce. Biasanya semakin murah biaya teknologi yang digunakan, akan semakin cepat di adopsi dan di implementasikan dalam sebuah organisasi.

4. Beberapa indikator faktor organisasional adalah kesiapan teknologi, ukuran perusahaan

Kesiapan teknologi merupakan sejauh mana infrastruktur teknologi sesuai dengan sistem dan kemapuan teknikal pada bisnis mampu mendukung adopsi e commerce (Zhu dkk, 2006). Kesiapan teknologi terdiri dari teknologi infrastruktur dan tenaga teknologi informasi (Zhu \& Kraemer, 2005) dan keduanya mutlak dibutuhkan jika perusahaan ingin mengadopsi e business sebagai sebuah bagian integral dari rantai nilai. (Tiago \& Maria, 2010). Sedangkan ukuran perusahaan berhubungan dengan kemampuan perusahaan untuk menyiapkan sumberdaya seperti keuangan dan sumber daya manusia. Semakin besar ukuran perusahaan maka semakin besar kemampuan untuk menyiapkan sumber daya yang dibutuhkan, dan lebih memungkinkan untuk mengadopsi teknologi $e$ commerce.

6. Faktor lingkungan adalah pengaruh eksternal, seperti tekanan dari konsumen/supplier, pesaing dan dukungan eksternal lainnya yang mempengaruhi adopsi e commerce. Semakin tinggi tekanan dari rekan bisnis maka akan meungkinkan perusahaan untuk mengadopsi e commerce dengan tujuan untuk mempertahankan posisi kompetitif mereka (Duan,Deng \& Corbitt,2012). Semakin tinggi tekanan dari kompetitor dalam sebuah industri, perusahaan akan dipaksa untuk mengadopsi teknologi $e$ commerce untuk memperoleh keuntungan yang kompetitif. Semakin tinggi tingkat persaingan dalam sebuah industri, makin besar pula manfaat yang diperoleh dari pengadopsian e commerce. (Zhu \& Kraemer, 2005). Selain tekanan dari konsumen, supplier dan pesaing, ada juga dukungan dari pihak eksternal seperti pemerintah dan pihak penyedia teknologi informasi sebagai salah satu faktor yang yang mempengaruhi adopsi e commerce.

7. Indikator faktor individual yang digunakan dalam penelitian ini adalah inovasi dari pemilik usaha, pengalaman dan kemampuan penggunaan teknologi informasi dari pemilik. Inovasi dari pemilik adalah sejauh mana pemiliki usaha mengadposi inovasi lebih cepat dibandingkan lainnya dalam konteks sosial (Marcati,Guido, Peluso,2008), sedangkan jika pemilik usaha memiliki pengalaman dan kemampuan terkait teknologi informasi, mereka akan percaya diri dan lebih cepat dalam mengadopsi e commerce.

\section{$>$ Metode Analisis Data}

Metode analisis dalam penelitian ini menggunakan perhitungan analisis regresi berganda dimana untuk dipergunakan melihat pengaruh tidak langsung antara satu variable dengan variable lainnya. Untuk menyelesaikan persamaan regresi linier berganda dipergunakan software SPSS versi 20.0.

1. Uji Validitas
Untuk mengukur
kecermatan dan ketepatan suatu instrumen


pengukuran (kuesioner) dalam mengukur variabel (X1), variabel (X2) terhadap variabel (Y1) dan variabel (Y2) dilakukan uji validitas dan reliabilitas. Uji Validitas dilakukan untuk mengetahui seberapa baik suatu instrumen mengukur konsep yang seharusnya diukur. Kuesioner dikatakan valid apabila koefisien korelasi product moment melebihi 0,3, (Sugiyono, 2009).

\section{Uji Reliabilitas.}

Uji Reliabilitas dilakukan untuk mengetahui tingkat konsistensi hasil pengukuran bila dilakukan pengukuran dua kali atau lebih terhadap gejala yang sama dengan alat ukur yang sama. Hasilnya ditunjukkan oleh sebuah indeks yang menunjukkan seberapa jauh alat ukur yang dapat dipercaya atau dapat diandalkan. Untuk menguji reliabilitas instrument penelitian ini digunakan Cronbach Alpha (Ghozali, 2007). Dalam hal ini apabila nilai koefisien alpha > 0,6 maka dapat dikatakan bahwa instrumen yang digunakan tersebut reliabel.

\section{Uji Normalitas}

Pengujian ini dilakukan sebelum analisis regresi agar kondisi estimator linear tidak bias yang terbaik (best linear unbias estimator). Model regresi yang baik adalah memilki distribusi data normal atau mendekati normal. Pada penelitian ini, uji normalitas dilakukan dengan dengan metode uji one sample Kosmogorov-smirnov,dimana jika Asyim-sig ( 2 tailed)>0,05 maka dapat dikatakan bahwa data berdistribusi normal (Ghozali, 2007).

\section{Analisis Regresi Linear Berganda}

Metode analisis pada penelitian ini menggunakan perhitungan analisis regresi. Analisis regresi adalah analisis yang mengukur pengaruh variabel bebas terhadap variabel terikat. Pengukuran pengaruh ini melibatkan satu variabel bebas (X) dan variabel terikat (Y), yang dinamakan analisis regresi linier berganda dengan rumus $\mathrm{Y}=\mathrm{a}+\mathrm{b}_{1} \mathrm{x}_{1}+\mathrm{b}_{2} \mathrm{x}_{2}+\mathrm{e}$. Nilai "a" adalah konstanta dan nilai "b" adalah koefisien regresi untuk variabel X.. Untuk menyelesaikan persamaan regresi linier digunakan software SPSS versi 20.0. Analisis ini menggunakan 2 sub struktur :

a. Sub Struktur Pertama : Adopsi Ecommerce dipengaruhi oleh aspek teknologi, aspek organisasional, aspek eksternal dan aspek individual

Gambar 3.1 :

Kerangka Sub Struktur Pertama

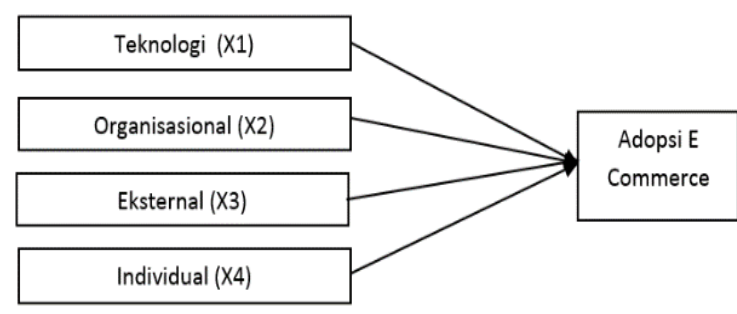

Persamaannya :

$\hat{\mathrm{Y}} 1=\mathrm{a}+\mathrm{b}_{1} \mathrm{X}_{1}+\mathrm{b}_{2} \mathrm{X}_{2}+\mathrm{b}_{3} \mathrm{X}_{3}+\mathrm{B}_{4} \mathrm{X}_{4}+\mathrm{e}$

Dimana : $\quad \mathrm{Y}=$ Adopsi e commerce $\mathrm{X}_{1}=$ Faktor Teknologi

$\mathrm{X}_{2}=$ Faktor Organisasional

$\mathrm{X}_{3}=$ Faktor Lingkungan

$\mathrm{X}_{4}=$ Faktor Individual

$\mathrm{a}=$ konstanta

$\mathrm{b}_{1}, \mathrm{~b}_{2}, \mathrm{~b}_{3}, \mathrm{~b}_{4}=$ koefisien regresi

$\mathrm{e}=$ error

b. Sub Struktur Kedua : Kinerja UMKM dipengaruhi oleh adopsi e commerce

Gambar 3.2

Kerangka Sub Struktur Kedua

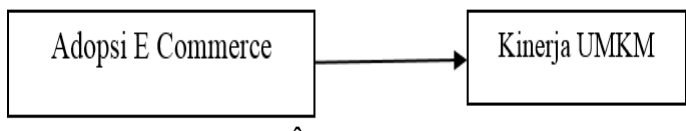

Persamaannya: $\quad \hat{\mathrm{Y}} 1=\mathrm{a}+\mathrm{b}_{1} \mathrm{X}_{1}+\mathrm{e}$

Dimana : $\mathrm{Y}=$ Kinerja UMKM

$\mathrm{X}_{1}=$ Adopsi e commerce

HASIL DAN PEMBAHASAN

\section{Hasil Pengumpulan Data}

\section{Penentuan Sampel}

Pengumpulan data dilakukan dengan cara menyebarkan kuesioner pada para responden yang merupakan pemilik UMKM di Kota Semarang yang sudah memanfaatkan inrenet dalam menjalankan bisnisnya. Kuesioner diditribusikan secara on line dan off line, yang disebar melalui berbagai komunitas pengusaha dan acara UMKM di Kota Semarang. Dari hasil pengumpulan kuesioner dihasilkan data distribusi kuesioner sebagai berikut :

Tabel 4.1

Distribusi Kuesioner

\begin{tabular}{|l|c|}
\hline Data disebar & 100 buah \\
\hline Kuesioner yang diterima & 100 buah \\
\hline Kuesioner tidak lengkap & 5 buah \\
\hline Kuesioner lengkap & 95 buah \\
\hline Respon Rate & $95 \%$ \\
\hline
\end{tabular}

Sumber : Data primer yang diolah (2017)

Kuesioner yang diterima sesuai dengan harapan, 
dari total kuesioner yang disebarkan sebanyak 100 buah, tetapi ada lima buah kuesioner yang tidak sah, karena tidak di isi secara lengkap. Model kuesioner yang digunakan dalam penelitian ini menggunakan skala Likert, dengan bentuk : STS (Sangat Tidak Setuju), TS (Tidak Setuju), KS (Kurang Setuju), N (Netral), AS (Agak Setuju), S (Setuju) dan SS (Sangat Setuju) dengan nilai jawaban $1-7$.

\section{Gambaran Umum Responden}

\section{Karakteristik Responden}

Dari data kuesioner yang telah disebarkan , didapatkan berbagai informasi terkait karakteristik responden dalam penelitian ini, diantaranya adalah, jenis kelamin, usia, latar belakang pendidikan, nilai omset dan jenis usaha.

\section{Tabel 4.2}

Karakteristik Responden Berdasarkan Gender

\begin{tabular}{|c|c|c|}
\hline Jenis Kelamin & Jumlah & Persentase \\
\hline Pria & 47 & $49,5 \%$ \\
\hline Wanita & 48 & $50,5 \%$ \\
\hline Total & 95 & $100 \%$ \\
\hline
\end{tabular}

Sumber : Data primer yang diolah (2017)

Berdasarkan data karakteristik responden menurut jenis kelamin, 49,5\% adalah pria dan sisanya $50,5 \%$ adalah wanita

Tabel 4.3

Karakterisik Responden Berdasarkan Usia

\begin{tabular}{|l|l|l|}
\hline Usia & Jumlah & Persentase \\
\hline $\begin{array}{l}\text { Dibawah } \\
30\end{array}$ & 44 & $46 \%$ \\
\hline $30-39$ & 38 & $40 \%$ \\
\hline $40-49$ & 11 & $12 \%$ \\
\hline Diatas 50 & 2 & $2 \%$ \\
\hline Total & 95 & $100 \%$ \\
\hline
\end{tabular}

Karakteristik responden berdasarkan usia, didominasi oleh usia dibawah 30 tahun sebanyak $46 \%$ dan responden yang paling sedikit adalah yang berumur di atas 50 tahun hanya sebanyak $2 \%$

Tabel 4.4

Karakteristik Responden berdasarkan Tingkat Pendidikan

\begin{tabular}{|c|c|c|}
\hline $\begin{array}{c}\text { Tingkat } \\
\text { Pendidikan }\end{array}$ & Jumlah & Persentase \\
\hline SMA & 22 & $23 \%$ \\
\hline Diploma & 14 & $15 \%$ \\
\hline S1 & 51 & $54 \%$ \\
\hline S2 & 8 & $8 \%$ \\
\hline Lainnya & 0 & - \\
\hline Total & 95 & $100 \%$ \\
\hline
\end{tabular}

Berdasarkan tabel diatas, mayoritas responden berlatar pendidikan lulusan Sarjana sebanyal 54 $\%$, lulusan SMA sebanyak $23 \%$ dan lulusan Diploma sebanyak $15 \%$, sedangkan yang pendidikannya Paska Sarjana adalah sebanyak $8 \%$.

Tabel 4.5

Karakteristrik Responden Berdasarkan Nilai Omset

\begin{tabular}{|l|l|l|}
\hline Nilai Omset & Jumlah & Persentase \\
\hline$<100$ juta/tahun & $\begin{array}{l}75 \\
\text { UMKM }\end{array}$ & $79 \%$ \\
\hline $\begin{array}{l}100-500 \\
\text { juta/tahun }\end{array}$ & $\begin{array}{l}16 \\
\text { UMKM }\end{array}$ & $17 \%$ \\
\hline $\begin{array}{l}500-1 \text { Milyar/ } \\
\text { tahun }\end{array}$ & 4 UMKM & $4 \%$ \\
\hline Total & $\begin{array}{l}95 \\
\text { UMKM }\end{array}$ & $100 \%$ \\
\hline
\end{tabular}

Nilai omset responden yang terbesar adalah dengan nilai $<100$ juta per tahun sebanyak $79 \%$, omset 100 juta - 500 juta per tahun sebanyak $17 \%$ dan omset senilai 500 juta - 1 Milyar per tahun sebnayak $4 \%$.

\section{Analisis Data dan Pembahasan}

Dari data-data yang sudah diperoleh, maka dilakukan pengolahan data analisis melalui beberapa uji statistik, seperti uji validitas, uji reliabilitas dan regresi linear.

1) Uji Validitas

Pengolahan data diawali dengan uji validitas dengan menggunakan koefisien $r$, yang didapat dari rumusan Korelasi Product Moment. Dengan menggunakan program SPSS 20.0, maka di peroleh angka korelasi setiap variabel sebagai berikut :

Hasil uji validitas untuk variabel aspek teknologi $\left(\mathrm{X}_{1}\right)$ berada pada rentang nilai $\mathrm{r}_{\text {hitung }}$ (Corrected Item-Total Correlation) antara 0,658 - 0,862, artinya kuesioner aspek teknoogi $\left(\mathrm{X}_{1}\right)$ tersebut valid, karena nilai pada item pertanyaannya lebih besar daripada nilai $r_{\text {tabel }} 0,2017$.

Tabel 4.6

Uji Validitas $\mathrm{X}_{1}$

\begin{tabular}{|c|c|c|c|c|}
\hline $\begin{array}{c}\text { Pearson } \\
\text { Correlation }\end{array}$ & $\mathrm{A} 1$ & $\mathrm{~A} 2$ & $\mathrm{~A} 3$ & ATOTAL \\
\hline $\mathrm{A} 1$ & 1 & $.331^{* *}$ & $.402^{* *}$ & $.658^{* *}$ \\
\hline $\mathrm{A} 2$ & $.331^{* *}$ & 1 & $.595^{* *}$ & $.846^{* *}$ \\
\hline $\mathrm{A} 3$ & $.402^{* *}$ & $.595^{* *}$ & 1 & $.862^{* *}$ \\
\hline ATOTAL & $.658^{* *}$ & $.846^{* *}$ & $.862^{* *}$ & 1 \\
\hline
\end{tabular}

Sumber : Data primer yang diolah (2017)

Hasil uji validitas untuk variabel aspek organisasional $\left(\mathrm{X}_{2}\right)$ berada pada rentang nilai rhitung (Corrected Item-Total Correlation) antara 0,513 - 0,760, artinya kuesioner aspek organisasional $\left(\mathrm{X}_{2}\right)$ tersebut valid, karena nilai pada item pertanyaannya lebih besar daripada nilai $r_{\text {tabel }} 0,2017$. 
Tabel 4.7

Uji Validitas $\mathbf{X}_{2}$

\begin{tabular}{|l|l|l|l|l|l|l|}
\hline $\begin{array}{l}\text { Pearson } \\
\text { Correlation }\end{array}$ & A4 & A5 & A6 & A7 & A8 & X2TOTAL \\
\hline A4 & 1 & $.337^{* *}$ & .158 & $.246^{*}$ & .170 & $.513^{* *}$ \\
\hline A5 & $.337^{* *}$ & 1 & $.395^{* *}$ & $.382^{* *}$ & $.347^{* *}$ & $.738^{* *}$ \\
\hline A6 & .158 & $.395^{* *}$ & 1 & $.461^{* *}$ & $.568^{* *}$ & $.730^{* *}$ \\
\hline A7 & $.246^{*}$ & $.382^{* *}$ & $.461^{* *}$ & 1 & $.445^{* *}$ & $.760^{* *}$ \\
\hline A8 & .170 & $.347^{* *}$ & $.568^{* *}$ & $.445^{* *}$ & 1 & $.715^{* *}$ \\
\hline X2TOTAL & $.513^{* *}$ & $.738^{* *}$ & $.730^{* *}$ & $.760^{* *}$ & $.715^{* *}$ & 1 \\
\hline
\end{tabular}

Sumber : Data primer yang diolah (2017)

Hasil uji validitas untuk variabel aspek eksternal $\left(\mathrm{X}_{3}\right)$ berada pada rentang nilai $\mathrm{r}_{\text {hitung }}$ (Corrected Item-Total Correlation) antara 0,683 - 0,840, artinya kuesioner aspek organisasional $\left(\mathrm{X}_{3}\right)$ tersebut valid, karena nilai pada item pertanyaannya lebih besar daripada nilai $r_{\text {tabel }}$ 0,2017 .

Tabel 4.8

Uji Validitas $\mathbf{X}_{3}$

\begin{tabular}{|l|l|l|l|l|l|}
\hline & A9 & A10 & A11 & A12 & X3TOTAL \\
\hline A9 & 1 & $.586^{* *}$ & $.494^{* *}$ & $.495^{* *}$ & $.827^{* *}$ \\
\hline A10 & $.586^{* *}$ & 1 & $.381^{* *}$ & $.592^{* *}$ & $.840^{* *}$ \\
\hline A11 & $.494^{* *}$ & $.381^{* *}$ & 1 & $.361^{* *}$ & $.683^{* *}$ \\
\hline A12 & $.495^{* *}$ & $.592^{* *}$ & $.361^{* *}$ & 1 & $.780^{* *}$ \\
\hline X3TOTAL & $.827^{* *}$ & $.840^{* *}$ & $.683^{* *}$ & $.780^{* *}$ & 1 \\
\hline
\end{tabular}

Sumber : Data primer yang diolah (2017)

Hasil uji validitas untuk variabel aspek individual $\left(\mathrm{X}_{4}\right)$ berada pada rentang nilai $\mathrm{r}_{\text {hitung }}$ (Corrected Item-Total Correlation) antara 0,828 - 0,910, artinya kuesioner aspek individual $\left(\mathrm{X}_{4}\right)$ tersebut valid, karena nilai pada item pertanyaannya lebih besar daripada nilai $r_{\text {tabel }} 0,2017$.

Tabel 4.9

Uji Validitas $\mathbf{X}_{4}$

\begin{tabular}{|l|l|l|l|l|}
\hline $\begin{array}{l}\text { Pearson } \\
\text { Correlation }\end{array}$ & A13 & A14 & A15 & X4TOTAL \\
\hline A13 & 1 & $.596^{* *}$ & $.628^{* *}$ & $.828^{* *}$ \\
\hline A14 & $.596^{* *}$ & 1 & $.781^{* *}$ & $.910^{* *}$ \\
\hline A15 & $.628^{* *}$ & $.781^{* *}$ & 1 & $.908^{* *}$ \\
\hline X4TOTAL & $.828^{* *}$ & $.910^{* *}$ & $.908^{* *}$ & 1 \\
\hline
\end{tabular}

Sumber : Data primer yang diolah (2017)

Hasil uji validitas untuk variabel adopsi $e$ commerce $\left(\mathrm{Y}_{1}\right)$ berada pada rentang nilai $\mathrm{r}_{\text {hitung }}$ (Corrected Item-Total Correlation) antara 0,821 0,861 , artinya kuesioner adopsi e commerce ( $\left.\mathrm{Y}_{1}\right)$ tersebut valid, karena nilai pada item pertanyaannya lebih besar daripada nilai $r_{\text {tabel }}$ 0,2017

Tabel 4.10

Uji Validitas $Y_{1}$

\begin{tabular}{|l|l|l|l|l|l|l|}
\hline Pearson Correlation & A16 & A17 & A18 & A19 & A20 & Y1TOTAL \\
\hline A16 & 1 & $.668^{* *}$ & $.443^{* *}$ & $.593^{* *}$ & $.748^{* *}$ & $.827^{* *}$ \\
\hline A17 & $.668^{* *}$ & 1 & $.685^{* *}$ & $.607^{* *}$ & $.560^{* *}$ & $.861^{* *}$ \\
\hline A18 & $.443^{* *}$ & $.685^{* *}$ & 1 & $.515^{* *}$ & $.433^{* *}$ & $.770^{* *}$ \\
\hline A19 & $.593^{* *}$ & $.607^{* *}$ & $.515^{* *}$ & 1 & $.692^{* *}$ & $.828^{* *}$ \\
\hline A20 & $.748^{* *}$ & $.560^{* *}$ & $.433^{* *}$ & $.692^{* *}$ & 1 & $.821^{* *}$ \\
\hline Y1TOTAL & $.827^{* *}$ & $.861^{* *}$ & $.770^{* *}$ & $.828^{* *}$ & $.821^{* *}$ & 1 \\
\hline
\end{tabular}

Sumber : Data primer yang diolah (2017)

Hasil uji validitas untuk variabel kinerja UMKM $\left(\mathrm{Y}_{2}\right)$ berada pada rentang nilai $\mathrm{r}_{\text {hitung }}$ (Corrected Item-Total Correlation) antara 0,896 - 0,945, artinya kuesioner aspek individual (X4) tersebut valid, karena nilai pada item pertanyaannya lebih besar daripada nilai $r_{\text {tabel }}$ 0,2017.

Tabel 4.11

Uji Validitas $\mathrm{Y}_{2}$

\begin{tabular}{|l|l|l|l|l|}
\hline $\begin{array}{c}\text { Pearson } \\
\text { Correlation }\end{array}$ & \multicolumn{1}{|c|}{ A21 } & \multicolumn{1}{|c|}{ A22 } & \multicolumn{1}{|c|}{ A23 } & \multicolumn{1}{|c|}{ A24 } \\
\hline A21 & 1 & $.829^{* *}$ & $.780^{* *}$ & $.945^{* *}$ \\
\hline A22 & $.829^{* *}$ & 1 & $.718^{* *}$ & $.925^{* *}$ \\
\hline A23 & $.780^{* *}$ & $.718^{* *}$ & 1 & $.896^{* *}$ \\
\hline Y2TOTAL & $.945^{* *}$ & $.925^{* *}$ & $.896^{* *}$ & 1 \\
\hline
\end{tabular}

Sumber : Data primer yang diolah (2017)

\section{2) Hasil Uji Reliabilitas}

Uji konsistensi internal (uji reliabilitas) dilakukan dengan menghitung koefisien (Crobanch Alpha) dari masing-masing instrumen dalam satu variabel. Instrumen yang dipakai dalam variabel tersebut dikatakan andal (reliabel) bila memiliki koefisien Crobanch Alpha lebih dari 0,60 (Nunnaly) dalam Imam Ghozali, 2001). Berdasarkan hasil uji reliabilitas terlihat semua variabel memiliki koefisien alpha lebih besar dari 0,60 sehingga instrumen penelitian ini dapat dikatakan handal (reliabel) dan dapat di katakan handal dan dapat dipakai sebagai alat ukur.

Tabel 4.12

Uji Reliabilitas

\begin{tabular}{|c|c|c|}
\hline Item & Crobanch Alpha & N of Items \\
\hline $\mathrm{X} 1$ & 0,706 & 3 \\
\hline $\mathrm{X} 2$ & 0,729 & 5 \\
\hline $\mathrm{X} 3$ & 0,791 & 4 \\
\hline $\mathrm{X} 4$ & 0,856 & 3 \\
\hline $\mathrm{Y} 1$ & 0,875 & 5 \\
\hline $\mathrm{Y} 2$ & 0,912 & 3 \\
\hline
\end{tabular}

Sumber : Data primer di olah (2017)

dari hasil uji reliabilitas, yang dilihat adalah nilai cronbach's alpha yang kita peroleh sebesar 0.706 - 0.912 artinya kuesioner tingkat reliabilitas (keandalan) yang tinggi karena diatas 0.60.

\section{Uji Asumsi Klasik}

Pengujian terhadap asumsi klasik dengan program SPSS 20.0 yang dilakukan pada penelitian ini meliputi :

\section{1) Uji Normalitas}

Persyaratan dari uji normalitas data adalah jika data menyebar di sekitar garis diagonal dan mengikuti arah garis diagonal, maka model 
regresi memenuhi asumsi normalitas. Dari gambar 6.1 dapat dilihat jika data menyebar mengikuti garis diagonal. Model regresi ini telah memenuhi asumsi normalitas.

\section{Gambar 4.1 Uji Normalitas}

Dependent Variable: Y1

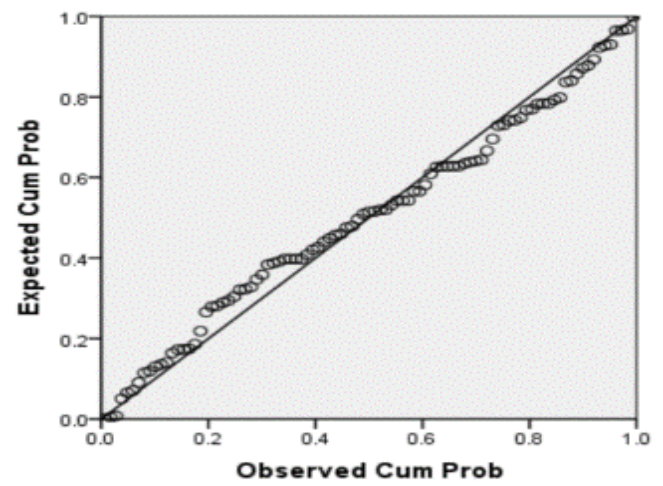

\section{Uji Autokorelasi}

Model regeresi yang baik adalah bebas dari autokorelasi. Dari pengujian dengan mengunakan Durbin Watson, didapatkan hasil sebagai berikut :

Tabel 4.13

Uji Durbin Watson

\begin{tabular}{|l|c|l|l|r|r|}
\hline Model & R & R Square & $\begin{array}{c}\text { Adjusted R } \\
\text { Square }\end{array}$ & $\begin{array}{c}\text { Std. Error of } \\
\text { the Estimate }\end{array}$ & $\begin{array}{c}\text { Durbin- } \\
\text { Watson }\end{array}$ \\
\hline 1 & $.721^{\mathrm{a}}$ & .520 & .499 & 2.735 & 2.161 \\
\hline
\end{tabular}

Sumber : data sekunder diolah (2017)

Berdasarkan tabel 4.13 didapatkan nilai DurbinWatson sebesar 2,161 yang berada pada range 1,55 - 2,46, maka dapat disimpulkan bahwa tidak ada autokorelasi.

\section{Uji Multikolinearitas}

Ada tidaknya multikolinearitas dapat dilihat dari nilai VIF (Variance Inflation Factors). Nilai VIF yang kecil menunjukkan tidak adanya korelasi yang tinggi (sempurna) antara variabel $\mathrm{X}$ dalam model regresi. Batasan nilai untuk variabel dikatakan berkolinieritas tinggi jika diperoleh nilai VIF untuk variabel independen lebih besar dari 10.

Tabel 4.14

Hasil Perhitungan Nilai Tolerance dan VIF

\begin{tabular}{|l|l|l|r|}
\hline \multicolumn{2}{|c|}{ Model } & \multicolumn{2}{c|}{ Collinearity Statistics } \\
\cline { 3 - 4 } & Tolerance & \multicolumn{1}{c|}{ VIF } \\
\hline \multirow{1}{*}{1} & (Constant) & & \\
\cline { 2 - 4 } & X1 & .569 & 1.758 \\
\cline { 2 - 4 } & X2 & .375 & 2.666 \\
\cline { 2 - 4 } & X3 & .430 & 2.328 \\
\cline { 2 - 4 } & X4 & .496 & 2.016 \\
\hline
\end{tabular}

Sumber : Data primer yang diolah (2017)

Dari tabel 4.14 di atas, dapat diketahui bahwa nilai Variance Inflation Factor (VIF) ketiga variabel lebih kecil dari 10, maka bisa disimpulkan bahwa antar variabel tidak terjadi persoalan multikolinearitas dan layak digunakan.

\section{Uji Heteroskedastisitas}

Model regresi yang baik adalah tidak terjadi heterokedastisitas. Dari pengujian dengan meggunakan uji Scatter Plot, dapat dilihat pada gambar 5.2, Berdasarkan uji Heterokedastisitas dengan menggunakan Scatter Plot menunjukkan tidak ada pola tertentu serta titik-titik menyebar di atas dan di bawah 0 pada sumbu Y, maka dapat disimpulkan bahwa tidak terjadi Heterokedastisitas.

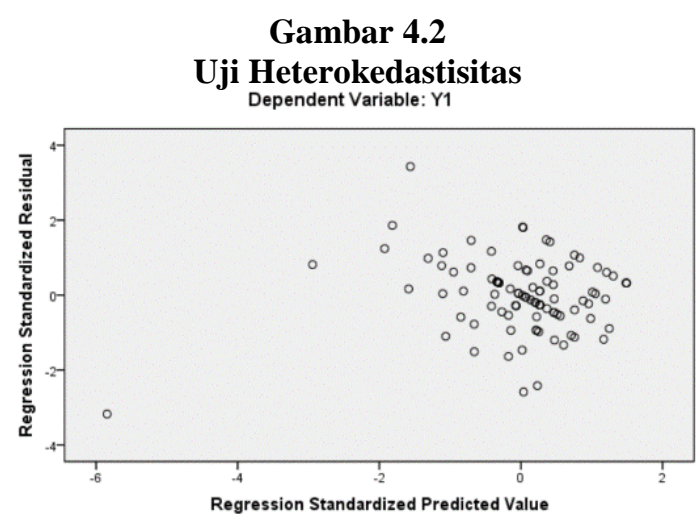

\section{Hasil Uji Analisis Regresi}

\section{Hasil Uji Regresi Linear Berganda}

Analisis regresi linear berganda adalah analisis tentang hubungan antara satu variabel dependen dengan dua atau lebih variabel Untuk menguji pengaruh faktor teknologi, organisasional, lingkungan dan individual terhadap adopsi $e$ commerce digunakan analisi regresi linear berganda.

Setelah dilakukan pengolahan data dengan bantuan program SPSS 20.0 maka didapatkan hasil pengolahan data sebagai berikut :

Tabel 4.15

Hasil Persamaan Regresi Berganda 


\begin{tabular}{|c|c|c|c|c|c|c|}
\hline & \multirow[b]{2}{*}{ Model } & \multicolumn{2}{|c|}{$\begin{array}{l}\text { Unstandardized } \\
\text { Coefficients }\end{array}$} & \multirow{2}{*}{$\begin{array}{c}\text { Standardized } \\
\text { Coefficients }\end{array}$} & \multirow[b]{2}{*}{$\mathrm{T}$} & \multirow[b]{2}{*}{ Sig. } \\
\hline & & B & Std. Error & & & \\
\hline \multirow[t]{5}{*}{1} & (Constant) & 10.301 & 2.251 & & 4.576 & .000 \\
\hline & $\mathrm{X} 1$ & .283 & .124 & .220 & 2.273 & .025 \\
\hline & $\mathrm{X} 2$ & -.003 & .119 & -.003 & -0.028 & .978 \\
\hline & $\mathrm{X} 3$ & .129 & .106 & .136 & 1.220 & .226 \\
\hline & $\mathrm{X} 4$ & .685 & .149 & .475 & 4.587 & .000 \\
\hline
\end{tabular}

Sumber : Data primer yang diolah (2017)

Berdasarkan hasil perhitungan pada tabel di atas, dapat dibuat persamaan regresi sebagai berikut :

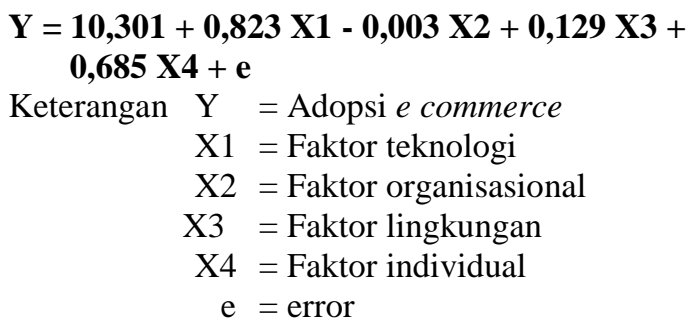

Dari persamaan regresi linier berganda diatas diperoleh nilai konstanta sebesar 10,301. Artinya, jika variabel Adopsi E Commerce (Y) tidak dipengaruhi oleh keempat variabel bebasnya atau Faktor Teknologi $\left(\mathrm{X}_{1}\right)$, Faktor Organisasional $\left(\mathrm{X}_{2}\right)$, Faktor lingkungan $\left(\mathrm{X}_{3}\right)$ dan Faktor Individual $\left(\mathrm{X}_{4}\right)$ bernilai nol, maka besarnya rata-rata Adopsi $E$ Commerce akan bernilai 10,301

Koefisien regresi untuk variabel bebas $\mathrm{X}_{1}$ (Faktor Teknologi) bernilai positif, menunjukkan adanya hubungan yang searah antara Faktor Teknologi $\left(\mathrm{X}_{1}\right)$ dengan Adopsi $E$ Commerce (Y). Koefisien regresi variabel $\mathrm{X}_{1}$ sebesar 0.823 mengandung arti untuk setiap pertambahan Teknologi $\left(\mathrm{X}_{1}\right)$ sebesar satu satuan akan menyebabkan meningkatnya Adopsi $E$ Commerce (Y) sebesar 0.823 .

Koefisien regresi untuk variabel bebas $\mathrm{X}_{2} \quad$ (Faktor Organisasional) bernilai negatif, menunjukkan adanya hubungan yang berlawanan antara Faktor Organisasional $\left(\mathrm{X}_{2}\right)$ dengan Adopsi E Commerce (Y). Koefisien regresi variabel $\mathrm{X}_{2}$ sebesar - 0,003 mengandung arti untuk setiap pertambahan Faktor Organisasional $\left(\mathrm{X}_{2}\right)$ sebesar satu satuan akan menyebabkan menurunnya Adopsi $E$ Commerce (Y) sebesar 0,003.

Koefisien regresi untuk variabel bebas $\mathrm{X}_{3}$ (Faktor Lingkungan) bernilai positif, menunjukkan adanya hubungan yang searah antara Faktor lingkungan $\left(\mathrm{X}_{3}\right)$ dengan Adopsi $E$ Commerce (Y). Koefisien regresi variabel $\mathrm{X}_{3}$ sebesar 0.129 mengandung arti untuk setiap pertambahan faktor lingkungan $\left(\mathrm{X}_{3}\right)$ sebesar satu satuan akan menyebabkan meningkatnya Adopsi E Commerce (Y) sebesar 0.129

Koefisien regresi untuk variabel bebas $\mathrm{X}_{4}$ (Faktor Individual) bernilai positif, menunjukkan adanya hubungan yang searah antara Faktor Individual $\left(\mathrm{X}_{4}\right)$ dengan Adopsi E Commerce (Y). Koefisien regresi variabel $\mathrm{X}_{4}$ sebesar 0,685 mengandung arti untuk setiap pertambahan Faktor Individual $\left(\mathrm{X}_{4}\right)$ sebesar satu satuan akan menyebabkan meningkatnya Adopsi E Commerce (Y) sebesar 0,685

\section{Hasil Uji Regresi Sederhana}

Analisis regresi linear sederhana adalah analisis tentang hubungan antara satu variabel dependen dengan satu variabel lainnya. Untuk menguji pengaruh adopsi e commerce terhadap kinerja UMKM. Setelah dilakukan pengolahan data dengan bantuan program SPSS 20.0 maka didapatkan hasil pengolahan data sebagai berikut :

Tabel 4.16

Hasil Persamaan Regresi Sederhana

\begin{tabular}{|c|c|c|c|c|c|c|}
\hline \multirow{2}{*}{\multicolumn{2}{|c|}{}} & \multicolumn{2}{|c|}{$\begin{array}{c}\text { Unstandardized } \\
\text { Coefficients }\end{array}$} & $\begin{array}{c}\text { Standardized } \\
\text { Coefficients }\end{array}$ & \multirow{2}{*}{} & \\
\cline { 2 - 5 } & Model & B & Std. Error & Beta & T & Sig. \\
\hline \multirow{2}{*}{1} & (Constant) & 3.002 & 1.488 & & 2.018 & .047 \\
\cline { 2 - 7 } & $\mathrm{X} 1$ & .510 & .049 & .732 & 10.362 & .000 \\
\hline
\end{tabular}

Sumber : Data primer yang diolah (2017)

Berdasarkan hasil perhitungan pada tabel di atas, dapat dibuat persamaan regresi sebagai berikut :

Keterangan

$$
\mathrm{Y}_{2}=3,002+0,510 \mathrm{Y}_{1}+\mathrm{e}
$$

$\mathrm{Y}_{2}=$ Kinerja UMKM

$\mathrm{Y}_{1}=$ Adopsi e commerce

$\mathrm{e}=$ error

Dari persamaan regresi linier diatas diperoleh nilai konstanta sebesar 3,002. Artinya, jika variabel Kinerja UMKM $\left(\mathrm{Y}_{2}\right)$ tidak dipengaruhi oleh variabel bebasnya atau Adopsi e commerce $\left(\mathrm{Y}_{1}\right)$ bernilai nol, maka besarnya rata-rata kinerja UMKM pada Kota Semarang akan bernilai 0,510 .

Koefisien regresi untuk variabel bebas adopsi $e$ commerce bernilai positif, menunjukkan adanya hubungan yang searah antara Adopsi $E$ Commerce dengan Kinerja UMKM pada Kota Semarang (Y). Koefisien regresi variabel $\mathrm{X}_{1}$ sebesar 0.510 mengandung arti untuk setiap pertambahan Adopsi E Commerce sebesar satu satuan akan menyebabkan meningkatnya Kinerja UMKM sebesar 0.510 .

\section{Uji Koefisien Detereminasi (R2)}

Pengujian ini melihat seberapa besar model regresi variabel dependen dijelaskan oleh variabel independen.

Tabel 4.17

Hasil Uji Koefisien Determinasi 


\begin{tabular}{|l|l|l|l|l|}
\hline Model & \multicolumn{1}{|c|}{ R } & R Square & $\begin{array}{l}\text { Adjusted } \\
\text { R Square }\end{array}$ & $\begin{array}{l}\text { Std. Error of } \\
\text { the Estimate }\end{array}$ \\
\hline 1 & $.721^{\mathrm{a}}$ & .520 & .499 & 2.735 \\
\hline
\end{tabular}

Sumber : data primer diolah (2017)

Dari tabel 6.13, besarnya $R$ Square sebesar 0,520. Hal ini berarti sebesar $52 \%$ variasi adopsi $e$ commerce dapat dijelaskan oleh keempat variabel independen, yaitu teknologi, organisasional, lingkungan dan individual, sedangkan sebesar $48 \%$ dijelaskan oleh variabel lain yang tidak di analisis dalam penelitian ini.

Tabel 4.18

Hasil Uji Koefisien Determinasi

\begin{tabular}{|c|c|c|c|c|}
\hline Model & R & R Square & Adjusted R Square & $\begin{array}{c}\text { Std. Error of } \\
\text { the Estimate }\end{array}$ \\
\hline 1 & $.732^{\mathrm{a}}$ & .536 & .531 & 1.845 \\
\hline
\end{tabular}

Sumber : Data primer yang diolah (2017)

Dari tabel 6.14, besarnya R Square sebesar 0,536. Hal ini berarti sebesar $53,6 \%$ variasi kinerja UMKM dapat dijelaskan oleh adopsi e commerce, sedangkan sebesar $46,4 \%$ dijelaskan oleh variabel lain yang tidak di analisis dalam penelitian ini.

\section{Pengujian Hipotesis}

\section{Pengujian Hipotesis secara Simultan}

Acuan yang digunakan dalam pengujian ini adalah dengan membandingkan nilai sig yang diperoleh dengan $\alpha=0,05$. Apabila nilai sig yang diperoleh lebih kecil dari derajat signifikansi, maka model yang digunakan sudah layak.

Tabel 4.19

\section{Hasil Uji Statistik F}

\begin{tabular}{|c|c|c|c|c|c|c|}
\hline \multicolumn{2}{|c|}{ Model } & $\begin{array}{l}\text { Sum of } \\
\text { Squares }\end{array}$ & Df & $\begin{array}{l}\text { Mean } \\
\text { Square }\end{array}$ & $F$ & Sig. \\
\hline \multirow[t]{3}{*}{1} & Regression & 729.816 & 4 & 182.454 & 24.396 & $.000^{\mathrm{a}}$ \\
\hline & Residual & 673.089 & 90 & 7.479 & & \\
\hline & Total & 1402.905 & 94 & & & \\
\hline
\end{tabular}

Sumber : Data primer yang diolah (2017)

Berdasarkan tabel 4.19 dapat diketahui hasil uji ANOVA atau $F$ test diperoleh hasil sebagai berikut :

\section{a. Berdasarkan $\mathrm{F}$ hitung dan $\mathrm{F}$ tabel}

Hasil tabel 4.19 didapat nilai $\mathrm{F}$ hitung sebesar 24,396. Adapun nilai F-tabel pada tingkat signifikansi $5 \%$ dan degree of freedom (df) sebesar $\mathrm{k}=5$ nilai $\mathrm{df} 1=\mathrm{k}-1=5-1=4$ sementara nilai df $2=\mathrm{n}-\mathrm{k}=95-5=90$. Bila pengujian dilaksanakan menggunakan nilai $\alpha=5 \%$, dengan begitu nilai $F_{\text {tabel }}$ yaitu sebesar 2,47 . Nilai $F_{\text {hitung }}>$ $F_{\text {tabel }}$ yaitu 24,396 > 2,47, sehingga hipotesis ke lima diterima. Hipotesis ke lima adalah diduga faktor kesiapan teknologi, faktor organisasional, faktor environment/lingkungan dan kesiapan individual berpengaruh secara bersama-sama terhadap adopsi e commerce pada UMKM di Kota Semarang.

b. Berdasarkan angka signifikansi

Pada tabel 5.15 dapat diketahui bahwa signifikansi sebesar $0,000<0,05$ sehingga dikatakan signifikan. Artinya , bahwa variabel faktor kesiapan teknologi, faktor organisasional, faktor environment/lingkungan dan pengetahuan individual berpengaruh secara bersama-sama terhadap adopsi e commerce pada UMKM di Kota Semarang.

\section{Pengujian Hipotesis secara Parsial (Uji t)}

Berdasarkan hasil perhitungan diperoleh hasil sebagai berikut :

Tabel 4.20

Hasil Uji Statistik t

\begin{tabular}{|l|c|c|c|c|}
\hline \multicolumn{1}{|c|}{ Variable } & $\begin{array}{c}\text { Koefisien } \\
\mathrm{B}\end{array}$ & $\mathrm{T}$ & Signifikansi & $\begin{array}{c}\text { Berpengaruh terhadap } \\
\text { adopsi ecommerce (Yl) }\end{array}$ \\
\hline $\mathrm{X}_{1}$ (Teknologi) & 0.283 & 2.273 & .025 & Berpengaruh \\
\hline $\mathrm{X}_{2}$ (Organisasional) & -0.003 & -0.028 & .978 & Tidak \\
\hline $\mathrm{X}_{3}$ (Lingkungan) & 0.129 & 1.220 & .226 & Tidak \\
\hline $\mathrm{X}_{4}$ (Individual) & 0.685 & 4.587 & .000 & Berpengaruh \\
\hline
\end{tabular}

Sumber : data primer diolah (2017)

Dari hasil uji statistik t pada tabel 4.20 diperoleh : 1. Pengujian pengaruh variabel faktor kesiapan teknologi $\left(\mathrm{X}_{1}\right)$ terhadap adopsi $e$ commerce $(\mathrm{Y})$

a. Berdasarkan $\mathrm{t}_{\text {hitung }}$ dan $\mathrm{t}_{\text {tabel }}$

Dapat dilihat bahwa $\mathrm{t}$ hitung variabel faktor teknologi sebesar 2,273. Pengujian hipotesis dengan $\alpha=5 \%$. Jika derajat bebas pengujian adalah $\mathrm{n}-\mathrm{k}=95-5=90$ maka nilai t tabel yaitu sebesar 1,664, maka didapat bahwa $\mathrm{t}$ hitung $>\mathrm{t}$ tabel yaitu 2,273>1,664, sehingga hipotesis pertama diterima. Hipotesis pertama adalah diduga faktor teknologi berpengaruh positif signifikan terhadap adopsi e commerce.

b. Berdasarkan angka signifikansi untuk variabel factor teknologi sebesar $0,025<0,05$ sehingga hasilnya signifikan. Artinya faktor teknologi berpengaruh positif signifikan terhadap adopsi e commerce.

2. Pengujian pengaruh variabel faktor organisasional $\left(\mathrm{X}_{2}\right)$ terhadap adopsi e commerce (Y)

a. Berdasarkan $t_{\text {hitung dan } t_{\text {tabel }}}$

Dapat dilihat bahwa $\mathrm{t}$ hitung variabel faktor organisasional sebesar - 0,028 Pengujian hipotesis dengan $\alpha=5 \%$. Jika derajat bebas pengujian adalah $\mathrm{n}-\mathrm{k}=95-5=90$ maka nilai $\mathrm{t}$ tabel yaitu sebesar 1,664, maka didapat bahwa $\mathrm{t}_{\text {hitung }}<\mathrm{t}$ tabel yaitu $-0,028<1,664$, 
sehingga hipotesis kedua ditolak. Hipotesis kedua adalah diduga faktor organisasional berpengaruh positif signifikan terhadap adopsi e commerce.

b.cBerdasarkan angka signifikansi untuk variabel faktor organisasional sebesar $0,978>0,05$ sehingga hasilnya tidak signifikan. Artinya faktor organisasional berpengaruh negatif dan tidak signifikan terhadap adopsi e commerce

3. Pengujian pengaruh variabel faktor lingkungan $\left(\mathrm{X}_{3}\right)$ terhadap adopsi e commerce $(\mathrm{Y})$

a. Berdasarkan $\mathrm{t}_{\text {hitung }}$ dan $\mathrm{t}_{\text {tabel }}$

Dapat dilihat bahwa t hitung variabel faktor lingkungan sebesar 1,220. Pengujian hipotesis dengan $\alpha=5 \%$. Jika derajat bebas pengujian adalah $\mathrm{n}-\mathrm{k}=95-5=90$ maka nilai $\mathrm{t}$ tabel yaitu sebesar 1,664, maka didapat bahwa $\mathrm{t}_{\text {hitung }}<\mathrm{t}$ tabel yaitu $1,220<1,664$, sehingga hipotesis ketiga ditolak. Hipotesis ketiga adalah diduga faktor lingkungan berpengaruh positif dan signifikan terhadap adopsi e commerce.

b. Berdasarkan angka signifikansi untuk variabel faktor lingkungan sebesar 0,226 >0,05 sehingga hasilnya tidak signifikan. Artinya faktor lingkungan berpengaruh positif dan tidak signifikan terhadap adopsi e commerce.

4. Pengujian pengaruh variabel faktor individual $\left(\mathrm{X}_{4}\right)$ terhadap adopsi e commerce $(\mathrm{Y})$

a. Berdasarkan $\mathrm{t}_{\text {hitung }}$ dan $\mathrm{t}_{\text {tabel }}$

Dapat dilihat bahwa $\mathrm{t}$ hitung variabel faktor individual sebesar 4,587. Pengujian hipotesis dengan $\alpha=5 \%$. Jika derajat bebas pengujian adalah $\mathrm{n}-\mathrm{k}=95-5=90$ maka nilai t tabel yaitu sebesar 1,664, maka didapat bahwa $\mathrm{t}_{\text {hitung }}>\mathrm{t}$ tabel yaitu 4,587 > 1,664, sehingga hipotesis keempat diterima. Hipotesis keempat adalah diduga faktor individual berpengaruh positif dan signifikan terhadap adopsi e commerce.

b. Berdasarkan angka signifikansi untuk variabel faktor individual sebesar $0,000<0,05$ sehingga hasilnya signifikan. Artinya faktor individual berpengaruh positif dan signifikan terhadap adopsi e commerce

Tabel 4.21

Hasil Uji Statistik untuk $Y_{2}$

\begin{tabular}{|c|c|c|c|c|}
\hline Variable & $\begin{array}{c}\text { Koefisien } \\
\mathrm{B}\end{array}$ & $\mathrm{T}$ & Sig. & $\begin{array}{l}\text { Berpengaruh terhadap } \\
\text { Kinerja UMKM }\left(\mathrm{Y}_{2}\right)\end{array}$ \\
\hline $\mathrm{X}_{1}$ (Adopsi $E$ Commerce) & 0.510 & 10,362 & .000 & Berpengaruh \\
\hline
\end{tabular}

Sumber : Data primer yang diolah (2017)

Dari hasil uji statistik t pada table 4.21 diperoleh : Pengujian pengaruh variabel adopsi e commerce $\left(\mathrm{Y}_{1}\right)$ terhadap adopsi kinerja UMKM $\left(\mathrm{Y}_{2}\right)$

a. Berdasarkan $t$ hitung dan $t$ tabel

Dapat dilihat bahwa t hitung variabel adopsi $e$ commerce sebesar 10,362. Pengujian hipotesis dengan $\alpha=5 \%$. Jika derajat bebas pengujian adalah $\mathrm{n}-\mathrm{k}=95-5=90$ maka nilai $\mathrm{t}$ tabel yaitu sebesar 1,664, maka didapat bahwa $\mathrm{t}$ hitung $>\mathrm{t}$ tabel yaitu 10,362 >1,664, sehingga hipotesis keenam diterima. Hipotesis kelima adalah diduga adopsi e commerce berpengaruh positif dan signifikan terhadap kinerja UMKM.

b. Berdasarkan angka signifikansi untuk variabel adopsi e commerce sebesar $0,000<0,05$ sehingga hasilnya signifikan. Artinya adopsi $e$ commerce berpengaruh positif signifikan terhadap kinerja UMKM.

\section{Pembahasan Hasil Penelitian}

\section{Pengaruh Teknologi terhadap Adopsi $E$ Commerce}

Berdasarkan tabel 4.20 didapatkan hasil bahwa faktor teknologi berpengaruh positif terhadap adopsi e commerce. Hal ini dilihat dari $\mathrm{t}$ hitung $>\mathrm{t}$ tabel yaitu 2,273>1,664, dengan angka signifikansi 0,025 lebih kecil dari 0,05. Hal ini berarti apabila faktor teknologi meningkat maka adopsi e commerce akan meningkat. Dapat dijelaskan pada kasus ini, biaya menjadi salah satu faktor yang mempengaruhi UMKM di Indonesia dalam mengadosi e commerce.

Biasanya semakin murah biaya teknologi yang digunakan, akan semakin cepat di adopsi dan di implementasikan dalam sebuah organisasi (Premkumar \& Robert,1999 dalam Rahayu \& Day, 2015). Penelitian ini sejalan dengan penelitian yang dilakukan oleh Rita Rahayu dan John Day (2015) dimana dalam penelitiannya membuktikan bahwa faktor teknologi berpengaruh positif dan signifikan terhadap adopsi e commerce.

\section{Pengaruh Faktor Organisasional terhadap Adopsi $E$ Commerce \\ Berdasarkan tabel 4.20 didapatkan hasil} bahwa faktor organisasional tidak berpengaruh signifikan dan negatif terhadap adopsi $e$ commerce. Hal ini dilihat dari $\mathrm{t}$ hitung $>\mathrm{t}$ tabel yaitu $-0,028<1,664$, dengan angka signifikansi 0,978 lebih besar dari 0,05 . Hal ini berarti apabila faktor organisasional meningkat maka adopsi $e$ commerce akan menurun. Dapat dijelaskan pada kasus ini hampir seluruh UMKM di Kota Semarang tidak menganggap bahwa ukuran perusahaan akan mempengaruhi mereka dalam mengadopsi e commerce, hal ini disebabkan UMKM di Semarang khususnya dan Indonesia pada umumnya masih berada pada level terendah dalam hal adopsi e commerce (Rahayu \& Day, 2013).

UMKM Kota Semarang hanya menggunakan email, media sosial ataupun website yang tidak dapat memaksimalkan peluang mereka untuk mengakses permodalan dari pihak perbankan, jika dibandingkan menggunakan Electronic Data Interchange (EDI), ada juga beberapa UMKM yang memiliki fasilitas teknologi namun tidak 
memahami dengan baik bagaimana pengelolaannya dan pemanfaatannya. Hasil penelitian ini sejalan dengan penelitian yang dilakukan oleh Ningtyas, PK., Sunarko B, Jaryono. (2015) serta Rita Rahayu dan John Day (2015) dimana dalam penelitiannya membuktikan bahwa faktor organisasional berpengaruh negatif dan tidak signifikan terhadap adopsi e commerce pada UMKM di Kota Semarang..

\section{Pengaruh Faktor Lingkungan terhadap Adopsi $E$ Commerce}

Berdasarkan tabel 4.20 didapatkan hasil bahwa faktor lingkungan berpengaruh positif dan tidak signifikan terhadap adopsi e commerce. Hal ini dilihat dari t hitung $<\mathrm{t}$ tabel yaitu $1,220<1,664$, dengan angka signifikansi 0,226 lebih besar dari 0,05 . Hal ini berarti apabila faktor lingkungan meningkat maka adopsi $e$ commerce akan meningkat. Hasil penelitian ini sejalan dengan hasil penelitian yang dilakukan Rita Rahayu dan John Day (2015), dimana pengaruh lingkungan berpengaruh positif dan tidak signifikan terhadap adopsi e commerce. Hasil ini bertentangan dengan hasil penelitian dari Ningtyas, PK., Sunarko B, Jaryono. (2015). Hal ini mengindikasikan bahwa tekanan dari pelanggan/supplier, tekanan dari kompetitor dan dorongan dari pihak eksternal tidak dianggap oleh UMKM di Kota Semarang sebagai faktor yang mempengaruhi mereka dalam mengadopsi e commerce. Penjelasan yang sangat mungkin untuk kondisi ini adalah bahwa konsumen di Indonesia, khususnya Semarang adalah seorang "online shopper with a conventional manner" (Panji, 2014), yang artinya konsumen hanya mengunjungi toko secara online untuk melihat produk yang ditawarkan, tapi jika mereka tertarik, mereka akan secara langsung bertransaksi baik melalui telepon, media sosial maupun tatap muka langsung. Dukungan pendampingan dan fasilitasi pelatihan dari pemerintah maupun dari rekan bisnis pun tidak menjadi jaminan bahwa UMKM akan mengadopsi e commerce.

\section{Pengaruh Faktor Individual terhadap Adopsi $\boldsymbol{E}$ Commerce}

Berdasarkan tabel 4.20 didapatkan hasil bahwa faktor individual berpengaruh positif dan signifikan terhadap adopsi e commerce. Hal ini dilihat dari t hitung > t tabel yaitu 4,587 >1,664, dengan angka signifikansi 0,000 lebih kecil dari 0,05 . Hal ini berarti apabila faktor individual meningkat maka adopsi e commerce akan meningkat. Hasil penelitian ini sejalan dengan hasil penelitian yang dilakukan Rita Rahayu dan John Day (2015), dimana pengaruh lingkungan memiliki pengaruh positif dan signifikan terhadap adopsi e commerce.

\section{Pengaruh Adopsi $E$ Commerce terhadap Kinerja UMKM}

Berdasarkan tabel 5.16 didapatkan hasil bahwa adopsi e commerce berpengaruh signifikan dan positif terhadap kinerja UMKM. Hal ini dilihat dari $\mathrm{t}$ hitung $>\mathrm{t}$ tabel yaitu 10,362>1,664, dengan angka signifikansi 0,000 lebih kecil dari 0,05 . Hal ini berarti apabila adopsi e commerce meningkat maka kinerja UMKM akan meningkat. Hasil penelitian ini sejalan dengan hasil penelitian yang dilakukan oleh Fatmariani (2011) serta Ningtyas, PK. \& Sunarko B, Jaryono. (2015), dimana adopsi e commerce memiliki pengaruh positif dan signifikan terhadap kinerja UMKM.

\section{KESIMPULAN DAN SARAN}

\section{Kesimpulan}

Berdasarkan rumusan masalah, tujuan penelitian, landasan teori, hipotesis dan hasil penelitian yang dilakukan, maka dapat disimpulkan sebagai berikut :

1. Faktor teknologi secara parsial berpengaruh positif dan signifikan terhadap adopsi e commerce pada UMKM di Kota Semarang. Hal ini dilihat dari t hitung 2,273 yang lebih besar dari t tabel yaitu 1,664, dan tingkat signifikansi 0,025 yang lebih kecil dari 0,05.

2. Faktor organisasional secara parsial berpengaruh negatif dan tidak signifikan terhadap adopsi e commerce pada UMKM di Kota Semarang. Hal ini dilihat dari t hitung $-0,028$ yang lebih kecil dari $\mathrm{t}$ tabel 1,664, dan tingkat signifikansi 0,978 yang lebih besar dari 0,05

3. Faktor lingkungan secara parsial berpengaruh positif dan tidak signifikan terhadap adopsi e commerce pada UMKM di Kota Semarang. Hal ini dilihat dari t hitung 1,220 yang lebih kecil dari t tabel yaitu 1,664, dan tingkat signifikansi 0,226 lebih besar dari 0,05.

4. Faktor individual secara parsial berpengaruh positif dan signifikan terhadap adopsi e commerce pada UMKM di Kota Semarang. Hal ini dilihat dari t hitung 4,587 yang lebih besar dari $t$ tabel yaitu 1,664, dengan tingkat signifikansi 0,000 lebih kecil dari 0,05.

5. Faktor teknologi, faktor organisasional, faktor lingkungan dan individual secara simultan berpengaruh secara bersama-sama terhadap adopsi e commerce pada UMKM di Kota Semarang. Hal ini dapat dilihat dari nilai $\mathrm{F}$ hitung sebesar 24,396. Yang lebih besar dari F tabel sebesar 2,47, dengan tingkat signifikansi sebesar 0,000 lebih kecil dari 0,05.

6. Adopsi e commerce berpengaruh positif dan signifikan terhadap kinerja UMKM di Kota Semarang. Hal ini dilihat dari t hitung 10,362 yang lebih besar dari $t$ tabel yaitu 1,664, dengan tingkat signifikansi 0,000 lebih kecil dari 0,05. 


\section{Saran}

Berdasarkan beberapa kesimpulan tersebut di atas, maka implikasi dalam penelitian ini adalah sebagai berikut :

1. Untuk penelitian selanjutnya disarankan untuk terlebih dahulu meneliti jenis - jenis $e$ commerce yang digunakan oleh pelaku UMKM, dan memfokuskan pada pelaku Usaha Kecil Menengah (UKM) yang sudah lebih banyak mengadopsi E Commerce dalam bentuk yang lebih kompleks.

2. UMKM yang sudah mengadopsi E-Commerce dalam aktivitas usahanya sebaiknya dapat menggunakan website dan dapat secara rutin meng- update situsnya untuk dapat terus berhubungan dengan konsumen dan untuk meyakinkan konsumen bahwa UMKM tersebut memang benar-benar ada sehingga dapat memperluas wilayah dagang.

3. Departemen Perdagangangan dan Perindustrian Bidang UMKM sebaiknya melakukan sosialisasi, pelatihan, dan lainnya secara menyeluruh mengenai hal-hal yang berkaitan dengan kegiatan $E$ Commerce.

4. UMKM harus secara aktif mengikuti pelatihan maupun seminar terkait E Commere yang diadakan berbagai pihak sehingga UMKM dapat memaksimalkan kinerja UMKMnya melalui E Commerce.

\section{DAFTAR PUSTAKA}

Chwelos, Paul; Benbasat, Izak dan Dexter, AlbertS. (2000), "Research Report: Empirical Test of an EDI Adoption Model"

Duan, X, Deng,H., \& Corbitt, (2012) Evaluating the critical determinants for adopting e market in Australia small and medium sized enterprises. Management Research Review, 35.

Fatmariani (2011) "Pengaruh Adopsi Teknologi Informasi Open Source E Commerce terhadap Kinerja UKM dengan Faktor-Faktor Technology Acceptance Model (TAM) Sebagai Moderating Variabel, Jurnal TeknomatikaVol.1 No.1 Palembang STMIK PalComTech

Hunter, M.Gordon \& Tan, Felix B (2007), Strategic Use of IT for Gobal Organizatons, IG Publishing, Hersey New York.

http://disperindag.jabarprov.go.id/news/detail/ekst ernal/2016/05/12:02:40508c75c8507a2ae5223dfd 2faeb98122 https://m.tempo.co/read/news/2014/03/23/089564 637/baru-40-persen-ukmanfaatkan teknologiinformasi Minggu 23 Maret 2014

http://ebusiness.commerce .ubc.ca /internal/UBCBEBR2000-003.pdf

Ghozali, Imam. (2007). Analisis Multivariate Dengan Program SPSS. Cetakan Empat. Badan Penerbit Universitas diponegoro. Semarang

Morteza,G,Daniel,A-A.,\& Jose,B.-A (2011). Adoption of e commerce applications in SMEs. Industrial Management \& Data System,111(8),1238-1269, dooi $10.1108 / 02635571111170785$

Nelson, Matthew L. dan Shaw, Michael J. (2003), "The Adoption and Diffusion of Interorganizational System Standards and Process Innovations", http://www.si.umich.edu/misqstds/proceedings/14 6_258-301.pdf

Nguyen, T.H. \& Wearing, T.S. (2013) E Commerce adoption of customer relationship management (CRM) Technology in SME's: an empirical study. Journal os Small Business \& Enterprise Development, 20(4), 824-848.

Ningtyas, PK., Sunarko B, Jaryono. (2015), “ Analisis Faktor yang Mempengaruhi Adopsi E Commerce dan Pengaruhnya terhadap Kinerja UMKM" Jurnal Performance Vol.21 No.1 , 1 Maret 2015

Panji, A. (2014) "4 Tantangan Bisnis E Commerce di Indonesia" Tekno, Kompas, http://tekno.kompas.com, 6 April 2014.

Rahayu, R. \& Day,J. (2013) E Commerce Adoption by Small and Medium Sized Enterprises in Indonesia: An Investigation of Influencing Factors and Benefits.

Rahayu, Rita \& Day, John (2015) Determinant Factors of E Commerce Adoption bu SMEs in Developing Country : Evidence from Indonesia. Procedia- Sociial dan Behavioural Science 195 (2015)142-150.doii

10.1016fj.sbspro.2015.06.423

Rahmidani, Rose (2015) "Penggunaan E Commerce dalam Bisnis sebagai Sumber Keunggulan Bersaing Perusahaan". Prosiding SNEMA, Padang. 
Roscoe, JT.(1975), Fundamental Research Statistics for the Behavioural Science, Holt, Rivehart \& Winston, New York.

Sarosa, Samiaji dan Zowghi, Didar (2003), "Strategy for Adopting Information Technology for SMEs: Experience in Adopting Email within an Indonesia Furniture Company", Electronic Journal of Information Systems EvaluationVol. 6, No. 2, pp. 165-176.

Shim, JK, Qureshi, A.A, Siegel, J.G \& Siegel, R.M.(2000) The International Handbook of $E$ Commerce, Chicago, Verlag.

Solechan,A dan Natalistyo (2011) E Commerce pada UKM Kota Semarang sebagai Model Pemasaran yang efektif. Prosiding SEMANTIK, Yogyakarta.

Sugiyono. (2009). Metode Penelitian Bisnis (Pendekatan Kuantitatif, Kualitatif, dan R\&D). Bandung: Alfabeta

Sulistyorini, Royanti, Yunianto (2014)“Pengaruh Adopsi E Commerce terhadap Keberhasilan Usaha" (Studi Kasus Pedagang Batik di Pasar Grosir Setono), Jurnal LITBANG Kota Pekalongan Tahun 2014.

Suyanto,M (2003) Strategi Periklanan pada E Commerce Perusahaan Top Dunia, Penerbit Andi, Yogyakarta

Tiago,0 \& Maria,F.M (2010). Understanding $e$ business adaption across inndustries in Europe countries. Industrial Management \& Data System, 110(9), 1337-1354.doi:10.1108/02635571087428

Yulimar, VA dan Setiawan, A (2008), Analisis Faktor -Faktor yang mempengaruhi Pengadopsian Electronic Commerce dan Pengaruhnya terhadap Kinerja Perusahaan (Studi Kasus Pengusaha Kecil dan Menengah di Indonesia), Seminar Nasional Aplikasi Sains dan Teknologi, - IST AKPRIND Yogyakarta

Zhu,K, \& Kraemer,K. L.(2005) Post adopstions variations in usage and value of $e$ business by organizations : cross country evidence from theretail industry. Informastion System Research, 16(1),61-84 